no heralding of their plans. The Commercial Club of New Salem aids them in every way it can; but it took a hand in this matter only after it was well under way and deserves only the credit of aiding an enterprise already in progress.

I believe the explanation of their success is the absence of petty jealousy, close church relationship, and frequent social intercourse, which is now greatly augmented by the rural telephone line, which reaches nearly every home in the settlement.

\title{
THE THEORY OF DYNAMIC HEREDITY IN THE LIGHT OF DATA GATHERED FROM THE DAIRY HERD OF THE MISSOURI AGRICULTURAL COLIEGE.
}

\section{F. S. Purney, Columbia, Mo.}

A recent writer in the biological world is Mr. Casper L. Redfield of Chicago, who has written various papers to promulgate a theory which he calls, "The Theory of Dynamic Heredity." It was with a view of testing his theory that a study was made by me of the birth rank of the dairy herd of the Missouri Agricultural College.

Mr. C. L. Redfield has given a lengthy discussion on his theory in Vol. 2, page 206, of the A. B. A., 190\%. This article of Mr. Redfield's is a summary by himself of his theory as found in "Control of Heredity," published by Monarch Book Company, the "Evolution of the Setter," published in American Field, beginning December 1\%, 1904, and in "Breeding the Trotter," published in the Horseman during 1905. Since this time he has also published an article entitled "The Development of the Holstein-Friesian Cattle," published by the Holstein-Friesian Register from April to June, 190\%. A summary of this latter work may be found in Vol. 4, page 24, of the Association's annual reports.

The chief point around which the following discussion centers was suggested by the statement of Mr. Redfield's (and it is one which he claims that he has proven) that: "It means that when breeders select those blood lines which they think are the best and are successful in their selection they are selecting unbeknown to themselves lines which come from old and well matured cows."

This work was suggested to me by Prof. F. B. Mumford because the herd of the Missouri Agricultural College offered unusual oppor- 
tunities in this regard. The following quotation from an article by Prof. C. H. Eckles will give a brief history of this herd: "In 1884 the Missouri Agricultural College bought four registered Jersey cows and the entire herd we have on hand to-day is descended from these cows. Of course, herd bulls have been purchased from outside but no female has been bought. Since 1892 complete milk and butter fat records have been kept of every cow. Until 1901 practically every female was retained in the herd regardless of her dairy qualities. These conditions give an opportunity to study the effect of sires which can hardly be duplicated anywhere."

The following is a list of the bulls used in improving the herd, together with a number of their daughters:



The value of Mr. Redfield's theory depends to quite a degree upon the accuracy of his data. The only question of said accuracy that has yet appeared to my notice is that offered by F. W. Marshall of the Ohio State University, who says in the American Naturalist of January, 1909: "I have recently completed some work with the trotting horse records, the result of which may be of interest inasmuch as it does not corroborate the results of other work in the same field." He makes a most careful comparison of his study with that made by Mr. Redfield and as a final conclusion says: "It is evident that the records do not reveal any superiority of the old sire over the younger one."

One hundred and forty-four pedigrees furnished the materiai for Redfield's articles. In the investigation of the college herd only forty-four were available.

Redfield determined by a study of one thousand cases the average age at which a Holstein-Friesian cow comés fresh, and used this calculated figure a great deal in his tabulated results. I made no efforts to secure such a figure for the Jerseys. The chief point was to see if daughters who produced more than their dams were of older birth rank.

The following pedigree is given as a sample of the way in which each of the forty-four was worked out: 
Pedigree of Alpha Elf and 93188, bred by Missouri Agricultural College. Fourth calf, dropped June 6, I893.

\section{Blrth Rank: 6.3.1.}

Sept. 10, 1887, Missouri Rioter
$\quad 19400(3.10 .22) \ldots \ldots \cdots \cdots \cdots \cdots$$\left\{\begin{array}{l}\text { May 26, 1879, Bachelor of St. L. } 4558(2.0 .25) \text {. } \\ \text { Oct. 18, 1883, Myrampo } 25512 \text { (7.6.27). }\end{array}\right.$

Mar. 5, 1887, Alphea Elf 47519 (Mar. 19, 1882, Edithson 8948 (5.11.3). (2.11.13)...............

March 5, 1875, Ocloff $3143(6.6 .7)\left\{\begin{array}{l}\text { Aug. 12, 1870, Lord Sisgar } 1066 . \\ \text { Aug. 28, 1868, Ophelie } 493 .\end{array}\right.$

May. 1, 1877, Chärity of St. L. \{ March 30, 1875, Stoke Pogis 3rd 2238. $6638(2.1 .4) \ldots \ldots \ldots \ldots \ldots \ldots\}$ March 27, 1875, Flore of St. Lambert 5526.

Oct. 30, 1879, Ramapo $4679\{$ April 6, 1877, Miletus 3186. (8. 2.17) $\ldots \ldots \ldots \ldots \ldots \ldots \ldots \ldots \ldots$ Aug. 13, 1871, Eurotos 2454.

Mar: 21, 1876, Myra 2nd 6289 July 18, 1873, Trusty (1101). (4.10.12)..............

Oct. $30,1879, \mathrm{R}$ a m a p o 4679 April 6, 1877, Miletus 3186. (8.2.17)...............

April 16, 1876, Lass Edith 6290 July 18, 1873, Trusty 1101. $(10.1 .24) \ldots \ldots \ldots \ldots \ldots \ldots \ldots\}$ Feb. 22, 1866, Edith 3rd 896.

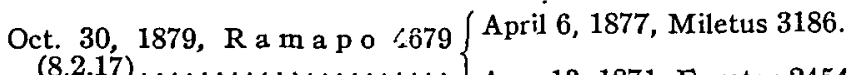
(8.2.17) ..............

Sept. 23, 1878, E l e m i 11840 (Oct. 15, 1874, Cecco 1673. (4.0.15) ............. (Sept. 8, 1874, Lerna 3634.

The numbers 6.3.1 represent the age in years, months, and days of Alphea Elf 47519 when she dropped Alphea Elf 2nd 93188, and is called the latter cow's birth rank. In like manner it will be seen that the birth rank of each parent, male and female, has been worked out for four generations. 
In this study I have made separate tables of the birth rank of the daughters of each of the different bulls, also noting the birth rank of the dams of sires and the dams of dams, but in this article I will give only the chief summary tables.

Summary table.



It is to be noted that the daughters of Minette's Pedro 50031 are of the oldest average birth rank, and that this bull is a medium quality as a sire. In average age the dams of sires in this case are the oldest, while the dams are next to the youngest. Professor Eckles said of him, "From good dams we secured good daughters; from inferior dams, inferior quality of daughters."

Another notable fact is that Missouri Rioter 3rd, with much the youngest birth rank among his three daughters, is by far the best bull that the college has owned as an improver of the herd.

In the -following table the cows are divided according to their production values regardless of their sires. 
Averagc birth rank of cows producing-

\begin{tabular}{|c|c|c|c|c|c|c|c|}
\hline \multicolumn{4}{|c|}{$\begin{array}{l}\text { Over } 300 \text { pounds of fat on the average } \\
\text { in one year. }\end{array}$} & \multicolumn{4}{|c|}{$\begin{array}{l}\text { Between } 250 \text { and } 300 \text { pounds of fat } \\
\text { on the average in one year. }\end{array}$} \\
\hline Name and number. & & Age. & & Name and number. & & Age. & \\
\hline & & M. & & & $\mathbf{Y}$. & M. & D. \\
\hline Bessie Bates $155372 \ldots \ldots \ldots$ & $\begin{array}{l}\mathbf{4} \\
\mathbf{4}\end{array}$ & & $\begin{array}{r}24 \\
4\end{array}$ & $\begin{array}{c}\text { Mattituck of St. L. 2nd } \\
\mathbf{9 3 3 6 4 \ldots \ldots \ldots \ldots \ldots}\end{array}$ & 5 & 3 & 28 \\
\hline Missouri Ramoposa 155373. & 5 & 5 & 9 & Ola Edens $134500 \ldots \ldots$ & 5 & 2 & 17 \\
\hline University Dazie 168596... & $\mathbf{5}$ & 10 & 11 & Vida Miller $134499 \ldots \ldots$ & 6 & 4 & 9 \\
\hline Pedro's Ramoposa 181168 . . & 6 & 3 & 11 & College Widow $146452 \ldots$ & 5 & 5 & 3 \\
\hline Pedro's Estella 197245. & 6 & 5 & 2 & Huguita $146451 \ldots \ldots$ & 5 & 5 & 14 \\
\hline Dazie Hildetta 116128. & 5 & 2 & 23 & Emily Harris 134735 . & 4 & 9 & 29 \\
\hline May Bates $108674 \ldots \ldots \ldots$ & 5 & 2 & 3 & Missouri St. L. $155370 \ldots$ & 5 & 6 & 6 \\
\hline Alphea Elf 4th $134498, \ldots$ & 6 & 3 & 15 & Dazie Columbia $146454 \ldots$ & 4 & 8 & 2 \\
\hline Estelle Thomas $134473 \ldots \ldots$ & 5 & 1 & 17 & College Susan 146453. & 5 & 5 & 13 \\
\hline \multirow{2}{*}{$\begin{array}{c}\text { Grace Briggs } 134732 \ldots \ldots \ldots \\
\text { Total } \ldots \ldots \ldots \ldots \ldots \ldots\end{array}$} & 5 & 5 & 20 & May Hubbard 134497..... & 5 & 5 & 5 \\
\hline & 60 & 8 & 19 & Pedro's Alphea Elf 168587. & 6 & 5 & 11 \\
\hline \multirow[t]{3}{*}{ Average............. } & & 6 & 7 & $\begin{array}{l}\text { University Stella R } 168593 \\
\text { Miss Missouri } 181159 \ldots \\
\text { Columbia Huguita } 168589 .\end{array}$ & $\begin{array}{l}5 \\
6 \\
6\end{array}$ & $\begin{array}{l}6 \\
6 \\
4\end{array}$ & $\begin{array}{r}1 \\
17 \\
23\end{array}$ \\
\hline & & & & Total & 90 & 1 & 27 \\
\hline & & & & Average. & 5 & 7 & 19 \\
\hline
\end{tabular}

Average birth rank of dams of coiss producing under 250 pounds of fat in onc year on the avcragc.

\begin{tabular}{|c|c|c|c|c|c|c|c|c|c|}
\hline Name. & Number. & \multicolumn{3}{|c|}{ Age. } & Name. & Number. & \multicolumn{3}{|c|}{ Age. } \\
\hline & & & M. & & . & & $\mathbf{Y}$. & $\mathbf{M}$. & D. \\
\hline Bachelor's Girl 2nd. & 104986 & 5 & 10 & 19 & University Belle.. & 168594 & 5 & 11 & 29 \\
\hline Mrs. Alvord. . & 116129 & $\mathbf{5}$ & 6 & 3 & University May $T$. & 168590 & 6 & $\boldsymbol{\theta}$ & 15 \\
\hline Columbia Hugo.. & 116126 & 5 & 10 & 19 & Pedro's Elf . . . . . . . & 197242 & 6 & 2 & 1 \\
\hline Alpheä Ward. . & 134496 & $\mathbf{5}$ & 3 & 9 & Pedro's Dazie Bates. & 168588 & 6 & 1 & 11 \\
\hline Dazie Katberine. . & 134495 & 4 & 7 & 22 & University Elf & 168598 & 6 & 1 & 22 \\
\hline College Nina....... & 108673 & 6 & 3 & 25 & Pedro's Grace Briggs & 197836 & 6 & 6 & 17 \\
\hline Matron Marcella. & 116462 & 6 . & 4 & 21 & & & & & \\
\hline Missouri Herbert M. & 155371 & 5 & 5 & 26 & Total & & 98 & 2 & 10 \\
\hline Alphea Elf 2nd.. & 93188 & 5 & 9 & 6 & & & & & \\
\hline Mary Herbert $M$ 3rd. & 93365 & 4 & 9 & 28 & Average. & & 5 & 9 & $\boldsymbol{9}$ \\
\hline Dazie Bates 3rd. . & 93363 & 4 & 5 & 7 & & & & & \\
\hline
\end{tabular}


Summary table.

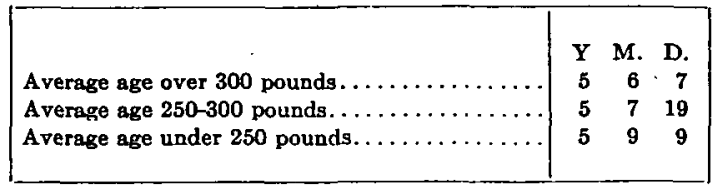

The following tables give birth rank of cows which have produced over 400 pounds in one year, and of those which have never produced over 250 pounds in one year:

Average birth rank of dams of cous producing over 400 pounds of fat in onc year.



Average birth rank of cows never producing over 250 pounds of fat in one year.

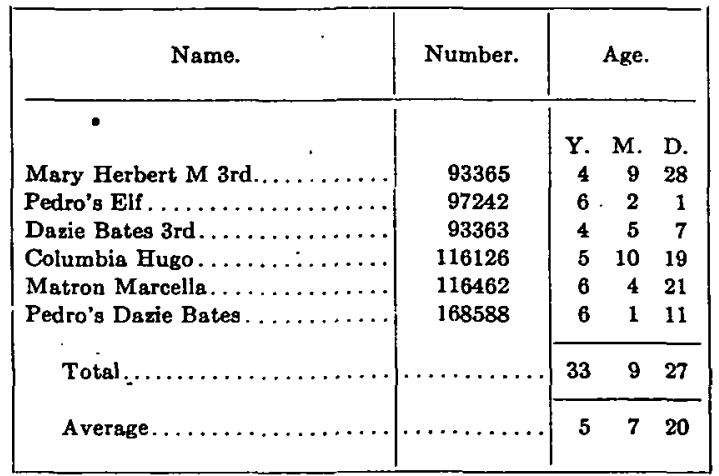


Summary table.

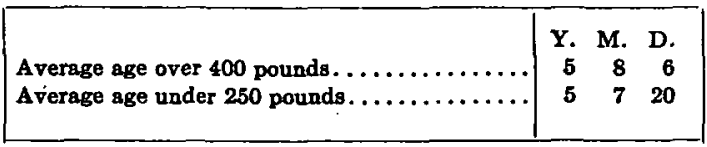

Thus, no great difference in average birth rank is to be noted.

A study was made of the birth rank of the grand-dams on the sire's side, since Mr. Redfield claimed much for the extreme birth rank of this individual. In the following summary table will be found results of the study:

Summary table.

\begin{tabular}{|r|r|rrr|}
\hline Average birth rank of grand-dams of cows pro- & Y. & M. & D. \\
duc!ng over 300 pounds fat $\ldots \ldots \ldots \ldots \ldots \ldots \ldots$ & 7 & 9 & 16 \\
Producing between 250 and 300 pounds....... & 6 & 4 & 3 \\
Producing under 250 pounds..................... & 8 & 1 & 14 \\
\hline
\end{tabular}

The difference here is greater and in all cases the results hig'.1er than was the average birth rank of all dams, but the poorest cows have the highest birth rank.

A study was also made of the birth rank of the cows that exceeded their immediate dams in butter fat yield, and of those that fell below. The result is shown in the following table:

Summary table.

\begin{tabular}{|l|rrr|r|}
\hline & & & & \\
Average birth rank of 31 cows exceeding....... & 5 & 8 & 17 \\
Average birth rank of 13 cows falling below.... & 5 & 11 & 1 \\
\hline
\end{tabular}

It will be seen that the little difference in favor of birth rank is with the poorer cows.

The conclusion to be drawn from the data found by a study of the college herd is perhaps of little practical use. It would point, however, to the fact that there is little benefit in aged or matured parents.

- To sum up results, then, of our previous statements as regards the history on the subject along with the investigation it would seem that, so far as we have any positive knowledge, we can only develop ability where it already existed in a latent state. It cannot be created. 
Let us, then, in breeding, select stock of high quality for mating purposes, and raise all of their healthy progeny. Develop the progeny to their highest possible limit and mate again in the same way. And then, if it is finally found to be true that acquired character or highly developed dynamic ability is inherited, we will have caused to be transmitted to future generations the best that modern science knows.

\section{INHERITANCE IN “BL,OOD INNES"' IN BREEDING ANHMALS FOR PERFORIMANCE, WITH SPECIAL REFERENCE TO THE " 200-EGG HEN." a \\ Raymond Peari.}

1. It has been generally assumed in breeding for performance in all animals, whether for egg production in poultry, or milk production in cattle, or speed in horses, etc., that the best and indeed practically the only criterion of an animal's worth or value as a breeder is its actual performance record. That is, it has been assumed that the animals which make the best performance records are, by virtue of that fact alone, the best individuals to breed from in any consistent and systematic attempt to improve the strain with reference to the character in regard to which the record was made. Performing ability is taken as the criterion of breeding worth. Thus, to take some illustrations, it was assumed at the beginning of experiments in increasing egg production by breeding at the Maine Station that " 200 egg hens" are the best hens to breed from in attempting to build up a high-laying strain. The fact that such birds had laid 200 or more eggs in a year was taken to be an indication that their offspring would be likely to lay more than the average number of eggs produced by the general flock. Again, in the case of dairy cattle, the assumption which lies at the basis of the advanced registries which exist for the principal dairy breeds, so far as such registries relate at all to the use of female animals as breeders, is that the heavy milker is, because of its performance, a more desirable female to breed from in attempting to bring about superior average performance in the herd than is the female of lower production.

2. The results of certain experimental studies in breeding for performance would appear to indicate that this common assumption

- Papers from the Blological Laboratory of the Maine Agricultural Experiment Station No. 19. 